\title{
A Response to "Doctors Challenges During Infectious Disease Outbreaks: Medical Education Insights from Realistic Fiction Movies" [Letter]
}

\author{
Natalie Ning Yan Choi' \\ Shreya Chawla ${ }^{2}$ \\ Hamza Nawaz (D) \\ 'Barts and the London School of \\ Medicine and Dentistry, London, UK; \\ ${ }^{2}$ Faculty of Life Sciences and Medicine, \\ King's College London, London, WC2R \\ 2LS, UK
}

\section{Dear editor}

We read with great interest the article "Doctors' Challenges During Infectious Disease Outbreaks: Medical Education Insights from Realistic Fiction Movies" by Daher-Nashif S. ${ }^{1}$ The selfless qualities of doctors portrayed in movies played important roles to inspire the decisions to pursue careers in medicine amongst many of our peers. We therefore reflect on the article with our current perspectives as 5th year medical students regarding the value of movies in medical education.

Medicine is a perpetual learning profession and methods for learning should not be limited to traditional resources. "Cinemeducation" is an established method of medical education with the utilization of movies, which has been shown to improve the understanding of various aspects in medicine, namely medical ethics and professionalism. ${ }^{2}$ Similarly, the author appreciates the potential value of using movies to understand the responsibilities and challenges faced by doctors during a pandemic. The topical nature of the article is again exemplified with the mention of female representation in positions of authority. Indeed, this encourages reflection as gender inequality remains a pertinent issue in the medical profession. ${ }^{3}$

The educational value of movies should not be disregarded, nevertheless accuracy of the information portrayed in movies is at times questionable. Storylines can often be exaggerated and dissimilar to real-life situations thus leading to potential risks of misapprehension. One of the analysed movies "Toxic Skies", depicts a conspiracy based on a "government's chem-trail program" that led to a pandemic. ${ }^{1}$ Researches have shown a rise in number of conspiracy theories surrounding COVID-19, therefore such depictions can shed a negative light on the government and instil mistrust in the society. ${ }^{4}$ These beliefs and their effects can be extremely detrimental to the public and pose significant challenges to doctors when managing these patients.

The author also recognizes a lack of mention of several key issues faced by doctors during infectious disease outbreaks. The time constraints on movies often results in bias towards the inclusion of the most gripping events and therefore unsurprising to focus on the depiction of front-line workers with little or no mention of doctors working in other settings. Another important point to bring to the readers' attention is that movies can often emphasize the importance of immediate
Correspondence: Natalie Ning Yan Choi Barts and the London School of Medicine and Dentistry, Garrod Building, Turner Street, Whitechapel, London, EI 2AD, UK

Tel +447472790796

Email n.y.choi@smdI6.qmul.ac.uk 
treatment for infected individuals, whilst better prevention and infection control may play equally significant parts in the grand scheme of a pandemic. ${ }^{5}$

A major limitation of the study was that non-English movies were not included for analysis. As a result, seven out of eight movies included in the paper were based in North America. A larger and more inclusive sample would perhaps provide a more representative reflection of doctors' experiences in countries with different socioeconomic and cultural backgrounds.

In conclusion, cinemeducation provides opportunities for reflections and recognition of professional values, behaviours and challenges faced by medical professionals during the COVID-19 pandemic. Nevertheless, we believe the application of critical thinking skills balanced with real-life clinical experience are fundamental to achieve a meaningful learning experience through movies.

\section{Disclosure}

The authors report no conflicts of interest in this communication.

\section{References}

1. Daher-Nashif S. Doctors' challenges during infectious disease outbreaks: medical education insights from realistic fiction movies. $A d v$ Med Educ Pract. 2021;12:265-272. doi:10.2147/AMEP.S297427

2. Darbyshire D, Baker P. A systematic review and thematic analysis of cinema in medical education [Internet]. Med Humanit. 2012;38 (1):28-33. doi:10.1136/medhum-2011-010026

3. De Simone S, Scano C. Discourses of sameness, unbalance and influence: dominant gender order in medicine. J Gend Stud. 2018;27 (8):914-927.

4. Ahmed W, Vidal-Alaball J, Downing J, Seguí FL. COVID-19 and the $5 \mathrm{G}$ conspiracy theory: social network analysis of twitter data. $J$ Med Internet Res. 2020;22(5):19458.

5. Güner R, Hasanoğlu İ, Aktaş F. Covid-19: prevention and control measures in community [Internet]. Turkish J Med Sci. 2020;50(SI1):571-577. doi:10.3906/sag-2004-146

Dove Medical Press encourages responsible, free and frank academic debate. The content of the Advances in Medical Education and Practice 'letters to the editor' section does not necessarily represent the views of Dove Medical Press, its officers, agents, employees, related entities or the Advances in Medical Education and Practice editors. While all reasonable steps have been taken to confirm the content of each letter, Dove Medical Press accepts no liability in respect of the content of any letter, nor is it responsible for the content and accuracy of any letter to the editor.

Advances in Medical Education and Practice

Dovepress

\section{Publish your work in this journal}

Advances in Medical Education and Practice is an international, peerreviewed, open access journal that aims to present and publish research on Medical Education covering medical, dental, nursing and allied health care professional education. The journal covers undergraduate education, postgraduate training and continuing medical education including emerging trends and innovative models linking education, research, and health care services. The manuscript management system is completely online and includes a very quick and fair peer-review system. Visit http://www.dovepress.com/testimonials.php to read real quotes from published authors. 